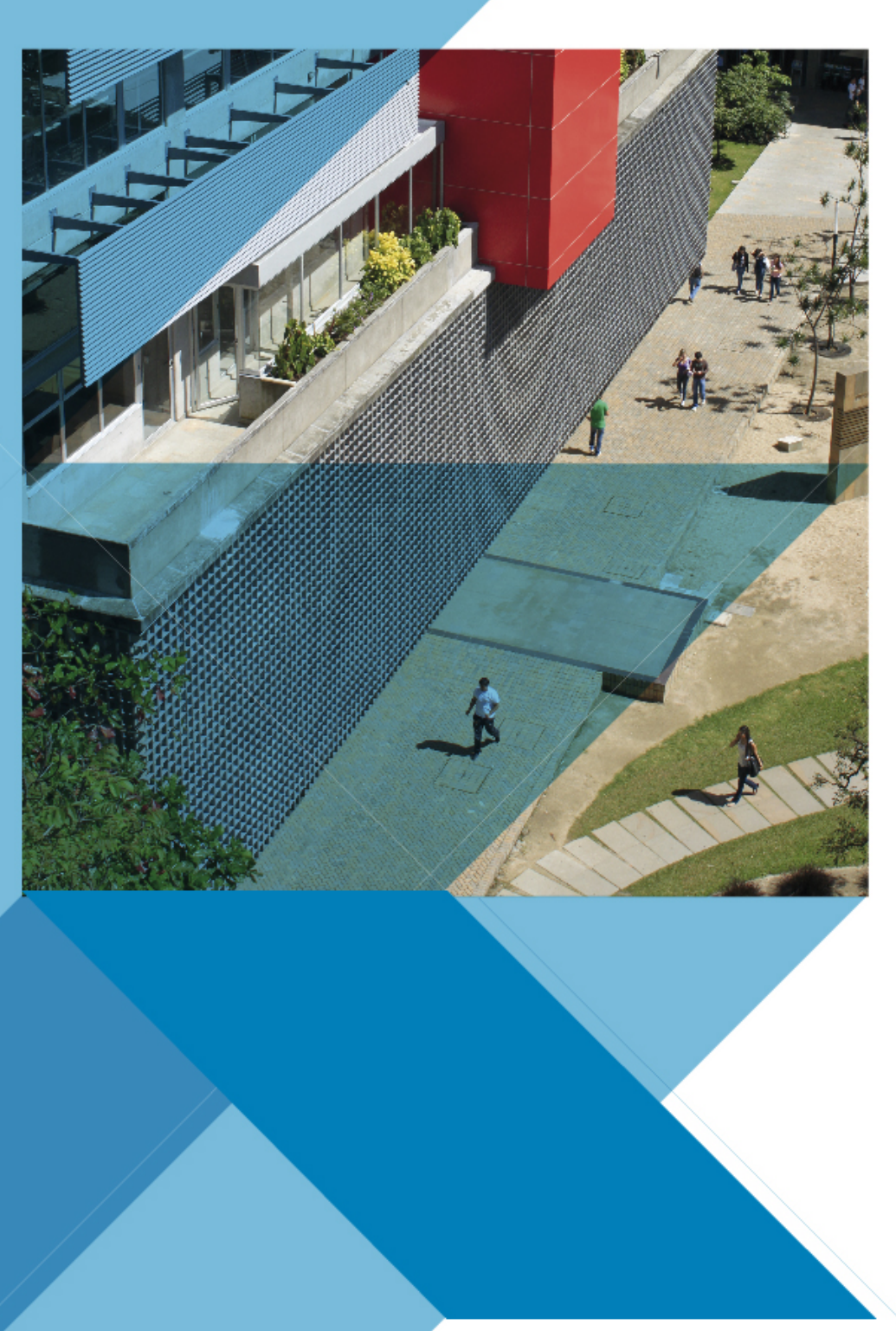

Escuela de Economía y Finanzas

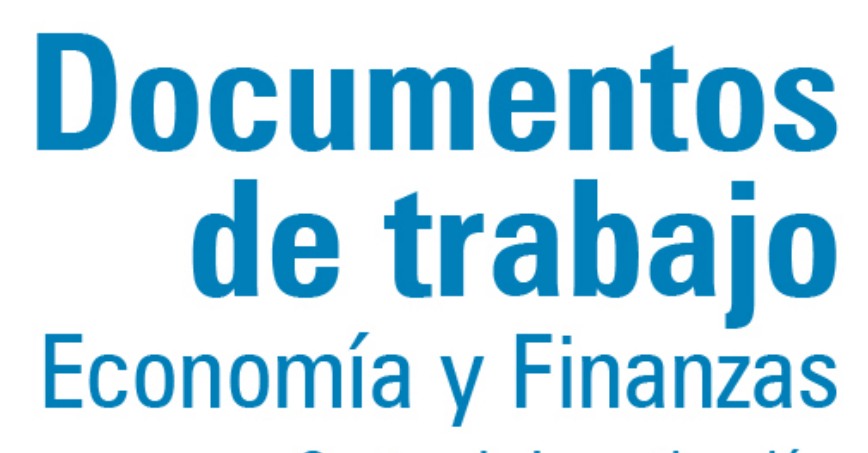

Centro de Investigación Económicas y Financieras

No. 13-29

European energy industry shocks, corporate 2013 control and firm's value

García, John J. ; Trillas, Francesc.

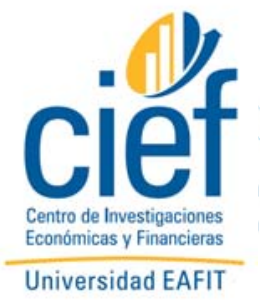




\title{
European energy industry shocks, corporate control and firms' value ${ }^{1}$
}

\author{
John J. García ${ }^{2}$ \\ Francesc Trillas ${ }^{3}$
}

\begin{abstract}
The deregulation process in the EU electricity sector triggered strategic decisions that led to industry restructuring. This paper presents preliminary evidence of the impact of this process on investors, using event studies and estimation techniques such as least squares and GARCH. Our findings suggest three stylized facts: 1) regulatory reform in Europe was certainly accompanied by a takeover wave, as predicted by Mitchell and Mulherin (1996); 2) mergers and acquisitions had a positive impact on the stock price of target firms, and a much lower and sometimes even a negative impact for the bidding firms; 3 ) the effect of takeover announcements on the returns of competitors of the merging firms depends on the degree of market power. In countries with high market power (like Spain) competitors significantly increase share returns upon takeover announcements, whereas in countries with lower market power (like England and Wales) returns do not change significantly.
\end{abstract}

\section{Classification JEL: L94, G14, G34, G38}

Keywords: Deregulation, mergers and acquisitions, event study, energy.

\footnotetext{
${ }^{1}$ We thank the comments and help from Gabriel Montes-Rojas, Georges Siotis, Josep Lluis Raymond, Juan Gallego and Mauricio Bedoya. And financial support from Universidad EAFIT, Medellín Colombia.

${ }^{2}$ Profesor Universidad EAFIT, Colombia. AA 3300 Medellín (Colombia). Phone: (+574)2619549, Fax: (+574)2664284. E-mail: jgarcia@eafit.edu.co

${ }^{3}$ Profesor Departamento de Economía Aplicada, Universitat Autònoma de Barcelona - Campus de la UAB, A.A. 08193 Bellaterra (Cerdanyola del Vallès) Barcelona - Spain. E-mail: francesc.trillas@uab.es.
} 


\section{Introduction}

This paper presents a preliminary investigation of the impact of regulatory reform in the European energy markets on the market for corporate control. Mitchell and Mulherin (1996) and Jensen (1993) found that factors such as changes in regulatory governmental policies had an important effect on the takeover wave in the financial, transport, and energy sectors of the USA in the 1980s and 1990s. Similarly, as we document below, energy firms undertook actions in the market for corporate control to adapt to the regulatory changes (liberalization, deregulation, regulatory reform, privatization) that took place in Europe starting in the last decades of the twentieth century. More specifically, these changes have triggered an unprecedented wave of mergers and acquisitions, many of them through takeovers (see Green, 2006; Trillas, 2006; and Codognet et al., 2002). However, there is very little work on the relationship between regulatory changes and corporate control activity. In particular, an exercise that has become standard for other industries (to compute through event studies the impact of corporate changes on shareholder value and extract economic implications from it) has not been extensively applied to European energy firms (see Trillas, 2001, for a very limited exception). This paper is a first attempt to fill this gap.

We provide information on the coincidence in time of regulatory reform and very significant changes in corporate ownership, and we quantify the impact of some corporate control events on transacting companies' stock returns through a range of estimation techniques, such as least squares, GARCH and SURE. We obtain three important results: 1) The European energy sectors have experienced a wave of mergers and acquisitions, which has been contemporaneous to the regulatory reform process. 2) There are statistically significant positive abnormal returns for target firms and weakly significant negative returns for the bidding firms; and 3) Takeovers have a positive effect on the value of competitors in a market characterized by high market power (Spain), and non-significantly different from zero effect on the value of competitors in a market characterized by low market power (England and Wales).

Significant changes in public policies or technology, supply and demand shocks, trigger changes in industry structure (see Weston et al., 1990; and Ravenscraft, 1987). European energy firms are a case in point; they do not stay as spectators of regulatory reform, but try to position themselves to face the new challenges. These actions take place in many instances through the market for corporate control. Event studies quantify 
the impact of hese actions on shareholder value, and this may provide a test for a variety of economic hypotheses. The methodology is based on measuring the reaction of shareholders' expectations in front of new information and, therefore, the expected effect on the firm's discounted value (see Fama et al., 1969; Binder, 1998; Campbell et al., 1997; and Khotari and Warner, 2006). A merger for example may create value for shareholders, through efficiencies caused by scale or scope economies, vertical integration, or through increased market power (see Cox and Portes, 1998; Bradley et al., 1988; and Eckbo, 1983). This paper uses OLS and GARCH estimation techniques to analize the impact of changes in the corporate control of the main European energy firms on their value, as measured through stock prices. Especifically, we first analyze target behavior through the impact of takeovers launched on Endesa, Hidrocantábrico, and Scottish Power. Next we look at the effect of takeovers on the returns of competing firms. ${ }^{4}$ And finally, we quantify the impact of mergers and acquisitions for eleven of the most important energy firms in Europe: E.ON, RWE, Endesa, Gas Natural, Iberdrola, Unión Fenosa, ENEL, ENI, Energías de Portugal, Suez and Vattenfall.

The Electricity and Gas Directives in the European Union, aiming at the creation of an Internal Market in energy, thus triggered a mergers and acquisitions wave. National and European authorities have taken a not always coherent stance vis-à-vis such processes, sometimes promoting the transactions and in other occasions opposing them. We review some takeover attempts that took place in the recent past, and report evidence on the winners and losers of this process, through stock market (event study) and other data.

National governments have not passively contemplated this takeover wave. For example, The Economist (September $1^{\text {st }}$,2006) reported that in preparation for the full liberalisation of Europe's energy markets, the Spanish government thought that it needed a national energy champion that could rival the gigawatts of Electricite de France and Germany's RWE. So it was backing Gas Natural, a Spanish gas company based in Barcelona, the Catalan capital, which launched a hostile bid for Endesa in September 2005, initially opposing a competing bid from E.On. At the same time, the French government was promoting the merger between Suez and Gaz de France to avoid a hostile approachment by Enel in the French energy markets. Other national governments, notably the British, were less eager to defend national champions.

\footnotetext{
${ }^{4}$ For example, for the three takeovers that had Endesa as target, we analyze their effect on the returns of Iberdrola and Unión Fenosa, which are Endesa's competitors in the Spanish electricity market.
} 
Mitchell and Mulherin (1996), Jensen (1993) and Weston et al. (1990), argue that firms in industries such as airlines, banking and natural gas, underwent a mergers and acquisitions wave as a result of federal deregulation at the end of the 1970s and early 1980s in the USA. Deregulation increases the importance of managerial role, thereby increasing the marginal benefits for shareholders of managerial monitoring, requiring more concentrated shareholding structures (Trillas, 2000). This can be useful to put in context the events that have taken place in European energy markets in the last ten years. Deregulation increases the costs of monitoring managers' behavior and injects uncertainty and instability in the business environment. In the midst of such instability, investors must determine which part of success or failure is owed to managers and which part is owed to factors beyond their control. Increased instability increases the costs of observing the managers' conduct, which also favors more concentrated structures.

With liberalization processes the frontiers of firms cease to be frozen. The expansion of regulated firms ${ }^{5}$ seeks to take advantage of new growth opportunities derived from the possibility of entering to compete with incumbent firms in other segments or geographical areas (in new markets, mergers and acquisitions attract less the attention of anti-trust authorities than in traditional markets). Being the incumbent firm in another jurisdiction makes a firm a more credible rival, and this intensifies competition. Nevertheless, the optimal size of the firm from the managers' point of view is usually higher than the optimal size for shareholders and for society at large (remember that some of the greatest corporate control scandals in the world have been related to the uncontrolled expansion of firms that were born in regulated sectors, such as Enron or Vivendi). Acquiring firms have the opportunity to diversify their revenue sources, and seek synergies with their traditional businesses, exploiting potential scale and scope economies. The countries that are recipient of investments, usually but not always developing countries, wish to import technology and capital. Some acquirers, not necessarily the most efficient, can benefit from predatory capital subsidies from the country of origin owing to generous regulation, or their managers can benefit from relaxed forms of control from their shareholders.

\footnotetext{
${ }^{5}$ In the U.S., one of the issues which was historically regulated was the possibility of expansion by electricity firms. The repeal of the Public Utility Holding Company Act in 2005 removed this constraint.
} 
Network industries subject to regulation, such as the electricity industry, are characterized by large sunk and long lived investments. To the extent that there are natural monopoly segments (distribution, transmission and system operation; in the past, generation and retail were deemed also part of a vertically integrated natural monopoly) price regulation of these parts of the industry becomes necessary, which results into the well-known time inconsistency problem of regulation: the regulator receives strong pressures not to remunerate sufficiently the investments, once these have occurred, so that investors lack the incentives to fund the investments in the first place. The different mechanisms that societies have historically developed to alleviate this problem have crucially affected the different forms of ownership of electricity firms that have existed. Public sector ownership of firms was during many decades the preferred form of alleviating the problem, because the firm used to internalize in its objective function the interests of consumers and investors. The presence of ownership mechanisms different from private ownership in the energy sectors of many countries must be seen in this context: state-owned firms, municipal firms, firms owned by regional or provincial governments, cooperatives, firms owned by non-profit saving banks. Popular capitalism (selling shares of previously state-owned firms to the dispersed public to spread stock ownership amongst the population, as promoted by the Thatcher governments in Britain in the eighties and early nineties) was also thought to internalize the problem, since voters/consumers became also investors. ${ }^{6}$ In countries such as Spain, where state-owned firms co-existed in the electricity sector with privately owned firms, collusion between policy makers and firms, and the presence of financial institutions among the stock owners, were also in practice a way to alleviate the time inconsistency problem in regulation, at the cost of other inefficiencies and of a serious legitimacy and transparency problem.

The presence of private investors in large electricity firms gives rise to agency problems, which must be compounded to regulatory risk problems. It is well-known that there are a variety of mechanisms, all of them costly and imperfect, to prevent managers from behaving in a non profit-maximizing way: a direct monitoring role by owners or boards of directors, monetary incentives, product market competition, managers' labor market competition, and takeovers.

\footnotetext{
${ }^{6}$ Rate of return regulation used to guarantee the value of investments and the supervising role of regulatory agencies was a subsidy to the monitoring task of shareholders. Incentive regulation ceased to guarantee a profit level, so that management decisions got their central role re-established, but again tension showed up in the form of a credibility problem to keep a fixed price.
} 
Takeovers in regulated sectors can in theory be a mechanism to control managers, although academic research (summarized by Trillas, 2000) reveals that takeovers have a lower success ratio, last longer until they are completed if they are completed at all, and are costlier in regulated sectors than in other sectors. Stakeholders use the regulatory game to mobilize themselves. Takeovers attract light to regulated sectors, which usually is detrimental to bidding firms, because consumer activism increases and this reduces the discounted value of future profits. The newly acquired saliency of regulatory issues makes consumers aware of their interest to exploit the sunk cost nature of regulated assets on the one hand, and gives them an incentive to incur the costs of making their voice heard because this time the media and the politicians are paying attention. The activism of other stakeholders, such as workers and local communities, is similarly affected. ${ }^{7}$ Takeovers take place with the theoretical objective of replacing inefficient managers with others that can obtain more value from the firm's assets. However, takeovers may destroy value if the managers of bidding firms overestimate their abilities, or if they wish to expand beyond what is optimal for their shareholders. Although one would expect that bad bidders become good targets, in practice public ownership, golden shares, and instruments of a similar nature make this very difficult in some countries. ${ }^{8}$

The fact that privatizations often coincide with deregulation processes makes it difficult to untangle the effects on productive efficiency of deregulation and the effects of privatization. Moreover, it is debatable whether in some countries as in Spain, ${ }^{9}$ the governance of privatized firms as a result of the new ownership structure are those that benefit more firms and industries that are in the midst of a deregulation process. However, it can certainly be that some privatizations manage to improve productive efficiency, being in any case an empirical matter.

After this introduction, the paper describes the regulatory changes that have taken place in Europe and their effects on firms' decisions. Next, we present some hypotheses and explain the methodology and data that will be used to test them. Finally,

\footnotetext{
${ }^{7}$ See Trillas (2001).

${ }^{8}$ The so-called golden shares were introduced in the United Kingdom in the eighties, and give the government veto power in strategic transactions such as ownership changes that alter the control structure of firms.

${ }^{9}$ Some of the outstanding patterns in the last ten years are the emergence in the Spanish electricity market of foreign firms still dominated by the public sector (ENEL in Viesgo, and Electricidade de Portugal in Hidrocantábrico), and the increasing influence of agents that have been successful in other industries in the Spanish economy in the recent past, such as saving banks and construction firms.
} 
we show the quantitative results in terms of the impact of corporate changes on the value of firms, and finally we conclude.

\section{Regulatory changes and implications for firms' behavior}

\subsection{Regulatory Changes in Europe}

After the pioneering experiences of the United Kingdom and Norway during the 1980s, the European Union started a gradual effort to liberalize the energy sectors. The starting point was the December 1996 96/92/CE electricity Directive, and the July 1998 98/30/C Gas Directive. These first directives established a compromise between the countries that had already started the liberalization and those that saw it as a very remote prospect. Member states had at that stage very different market structures, some with vertically integrated state owned national incumbents, and others with publicly or privately owned regional or local firms. The compromise had three main objectives : 1) Accounting separation between potentially competitive and monopolistic segments. 2) Freedom of choice for large consumers and 3) Increasing autonomy for transmission networks. $^{10}$

The implementation of these steps was slow and problematic. In some countries, such as France and Germany, those in charge of making decisions took from the outset a very hostile approach towards the process, setting very tough conditions to open their energy market. In 2003, a second package of directives established the full liberalization of supply for business and industrial customers by July 2004, and for all users including residential ones by July 2007. It also introduced the requirement that member states should create independent national regulatory agencies.

Again countries differed in the implementation of the second package (Green, 2006, Glachant and Finon, 2003). By 2005, in one extreme a small number of countries had completely liberalized their gas and electricity markets. In the other extreme France, Portugal, Italy and Greece fulfilled the minimum requirements of the first directives, but had only opened a small part of their energy industries to competition.

Cross-border electricity exchanges were quite scarce in that period. For example, according to EC (2007), in 2005, cross-border flows of consumed electricity in EU member-states plus Norway and Switzerland, only represented on average close to $11 \%$ of total consumption, which amounts to a pretty modest increase, given that in years

\footnotetext{
${ }^{10}$ See Trillas (2009).
} 
1998 and 2000 they were $7.5 \%$ and $8.9 \%$, respectively. In spite of increasing efforts to interconnect Europe, the integration process had resulted in the first decade of the twenty-first century into a number of fragmented markets (six in total, according to Haas et al. 2006).

In 2007 the Commission published the results of an investigation which criticized the state of competition in the electricity sector. ${ }^{11}$ Specifically, the Commission focused on three interrelated problems: 1) Excessive horizontal concentration in generation. 2) Excessive vertical integration between generation and transmission and, 3) scarce interconnection between national grids. As a result of this investigation, a third package of regulations was set in motion, through which the Commission had as objectives vertical separation and the interconnection of segmented markets. The package included the obligatory creation of independent system operators. The total separation between system operation and transmission ownership was initially considered as an option. This was not accepted by countries with vertically integrated incumbents (especially France and Germany). Additionally, the directives consolidated the authority of national independent regulators and created an EU-wide regulatory agency, based on the cooperation of national regulators (see Trillas, 2009).

Liberalization has not achieved the objective of effective competition in most energy markets, as shown by Green (2006) and Glachant and Lévêque, eds. (2009). But it has triggered a process of industry restructuring, as a result of which ownership concentration has increased (Green, 2006, and Trillas, 2006).

\subsection{Expansion and multimarket contact by European energy firms}

Several European firms in the energy sectors have enormously expanded during the recent years, as shown in García-Rendón (2010). It shows the volume of sales in a number of regions in 2006. The case of the two largest German firms, RWE and E.ON, is remarkable. The former made $60 \%$ of its sales in its country of origin, and the remaining $40 \%$ is shared between the United Kongdom (20.25\%), other EU countries $(13.5 \%)$ and $4 \%$ in American markets. The latter made only $56 \%$ of its sales in Germany. The Swedish Vattenfall made $40 \%$ of its sales in Sweden, $48 \%$ in other Scandinavian countries, 33\% in Germany and 6\% in Poland. Spanish firms (with a high

\footnotetext{
${ }^{11}$ See European Commission (2007).
} 
focus on Latin America), Italian ENI and British Centrica also show high levels of foreign activity.

Multi-market contact is one of the features that facilitates collusion. Firms that are asymmetric in a national market may see symmetry restored once market shares and efficiencies are compared at an international level. Relatedly, firms that may be under close scrutiny by national anti-trust authorities, may have more room of manœuvre in international markets, where market shares will be smaller. Collusion is easier to sustain when firms compete in more than one market. Of course, as many other features that facilitates collusion, this does not prove the existence of collusion, which is merely one of many possible equilibria of a repeated game.

Table 1 shows how this multi-market contact takes place for European gas and electictricity markets. Incumbent firms in one country are significant entrants in other countries. The table underestimates the scope of multi-market contact, to the extent that it does not show contacts in non-European countries and contacts in non-energy markets, such as telecommunications. Section 4 and García-Rendón (2010) give further details of the transformation that has been taking place in terms of industry structure. 
Table 1. Presence of the main energy firms in EU countries in 2004

\begin{tabular}{|c|c|c|c|c|}
\hline & Electricity & & Gas & \\
\hline Country & Largest & Other significant & Largest & Other significant \\
\hline Austria & VERBUND & RWE, E.ON, EDF & OMV & GDF, RWE \\
\hline Belgium & E-BEL & $\begin{array}{l}\text { EDF, ESSENT, } \\
\text { NOUN, CENTRICA }\end{array}$ & DISTRIGAS & $\begin{array}{l}\text { ESSENT, NUON, } \\
\text { CENTRICA }\end{array}$ \\
\hline Denmark & ELSAM & $\begin{array}{l}\text { E2, VATTENFALL, } \\
\text { E.ON }\end{array}$ & DONG & \\
\hline Finland & FORTUM & $\begin{array}{l}\text { VATTENFALL, } \\
\text { E.ON }\end{array}$ & GASUM & \\
\hline France & $\mathrm{EDF}$ & E-BEL, ENDESA & GDF & TOTAL \\
\hline Germany & RWE & $\begin{array}{l}\text { E.ON, } \\
\text { VATTENFALL, EDF }\end{array}$ & E.ON & $\begin{array}{l}\text { WINNGAS, RWE, } \\
\text { EXXON, SHELL }\end{array}$ \\
\hline Greece & PPC & & DEPA & \\
\hline Ireland & ESB & NIE & BGE & RWE \\
\hline Italy & ENEL & $\begin{array}{l}\text { E-BEL, ENDESA, } \\
\text { EDISON, VERBUND }\end{array}$ & ENI & EDISON \\
\hline Netherlands & E-BEL & $\begin{array}{l}\text { ESSENT, NOUN, } \\
\text { E.ON }\end{array}$ & SHELL & EXXON \\
\hline Portugal & EDP & ENDESA & GDP & \\
\hline Spain & ENDESA & $\begin{array}{l}\text { IBERDROLA, EDP, } \\
\text { ENEL, UNION } \\
\text { FENOSA }\end{array}$ & $\begin{array}{l}\text { GAS } \\
\text { NATURAL }\end{array}$ & $\begin{array}{l}\text { BP, IBERDROLA, } \\
\text { CEPSA }\end{array}$ \\
\hline Sweden & $\begin{array}{l}\text { VATTENFAL } \\
\text { L }\end{array}$ & E.ON, FORTUM & E.ON & DONG \\
\hline $\begin{array}{l}\text { United } \\
\text { Kingdom }\end{array}$ & & $\begin{array}{l}\text { EDF, E.ON, RWE, } \\
\text { CENTRICA }\end{array}$ & CENTRICA & $\begin{array}{l}\text { SHELL, EXXON, BP, } \\
\text { E.ON, EDF, RWE }\end{array}$ \\
\hline Poland & BOT & $\begin{array}{l}\text { PKE, PAK, E-BEL, } \\
\text { EDF }\end{array}$ & PGNIG & \\
\hline $\begin{array}{l}\text { Check } \\
\text { Republic }\end{array}$ & CEZ & RWE, E.ON & RWE & E.ON \\
\hline Slovakia & ENEL & $\begin{array}{l}\text { TEKO, RWE, EDF, } \\
\text { E.ON }\end{array}$ & $\begin{array}{l}\text { SPP(GDF, } \\
\text { E.ON) }\end{array}$ & \\
\hline $\begin{array}{l}\text { Hungary } \\
\text { Slovenia }\end{array}$ & $\begin{array}{l}\text { MVM } \\
\text { HSE }\end{array}$ & EDP, E.ON, RWE & $\begin{array}{l}\text { MOL } \\
\text { GEOPLIN }\end{array}$ & GDF, RWE, E.ON, ENI \\
\hline
\end{tabular}




\section{Hypotheses, methodology and data}

\subsection{Hypotheses}

Any expansion of firms raises questions about its impact on shareholder wealth. Event studies provide evidence of such impact, by measuring the abnormal returns associated to unanticipated events. To the extent that financial markets are efficient, event studies provide evidence on the impact of the announcements on the firm's stream of profits and, therefore, its discounted value. A merger can create value for shareholders if there are efficiency synergies (scope or scale economies, vertical integration) or if the merger increases market power. ${ }^{12}$ This usually translates into positive abnormal returns for target firms' shareholders, while stock prices of bidding firms may not significantly change (see Campa and Hernando, 2004, and Bradley et al., 1988). The literature explains this as a free-rider problem: shareholders only sell their shares if the bidding price equals the expected price of the shares after the takeover. Then any improvement in the value of the firm triggered by the change in management is captured by the shareholders of the target firm. It could also happen that value is destroyed as a result of the merger, if the bidding firm overpays for the target. This may be a signal that mergers are carried out for reasons that are unrelated to shareholder wealth. For example, the optimal size of the firm for managers may be larger than the optimal size from the point of view of the value of the firm (empire building).

We are interested in looking at empirical evidence through the lens of two hypotheses :

\section{Hypothesis 1:}

The value of target firms in the energy sector increases when a takeover is announced.

\section{Hypothesis 2:}

The effect of the announcement of a takeover on the value of competitiors depends on the existence of market power. If market power is high, competing firms experience statistically significant positive abnormal returns.

According to Bradley et al. (1988) a merger becomes an opportunity for the buying firm given the possibility of value creation, despite the costs of the transaction. Value creation may result from exogenous changes in supply or demand that increase

\footnotetext{
${ }^{12}$ Cox and Portes (1998).
} 
the profit maximizing firm size. Synergies may include more efficient management, or a better matching between management and physical assets. They may also include vertical efficiencies (through the elimination of double marginalization, through the internalization of externalities or through better incentives for sunk investments), or the combination of complementary resources. Finally, a higher value of the firm may be due to increased unilateral or multilateral market power that derives from a lower number of firms (Eckbo, 1983).

In most empirical studies, shareholders of acquired firms are the main winners of corporate transactions. Andrade et al. (2001) for example find that target shareholders in US takeovers between 1973 and 1998 make a positive return of 16\% on average upon announcement of a takeover, whereas bidding shareholders lose on average $0.7 \%$, but the statistical significance is very low.

Campa and Hernando (2004) find that the value generated for investors of target firms of mergers and acquisitions in the EU, receive, on average, statistically significant $9 \%$ cumulative abnormal returns, and that cumulative returns for bidding firms are zero. They also find that previously regulated firms experience comparatively lower abnormal returns.

It could be that improvements in social efficiency derived from a merger can be sufficiently high to compensate for the loss of welfare from collusion, if this exists. But if a merger increases the chances of collusion, it should be welcomed by shareholders of competing firms. The effect of a takeover or a merger announcement on non-merging competitors, however, is a topic that has been less explored from an empirical point of view. Eckbo (1983) argues that the sign of the expected effect on rivals is unclear. Abnormal returns could be positive, because the number of firms in the industry diminishes, and this increases unilateral (for example, in a Cournot model) and multilateral market power (in more general repeated oligopoly models), which also benefits the rivals of merging firms. But abnormal returns for rivals could also be negative, if they anticipate that the merging firms will be more efficient and therefore more competitive, hindering the profitability of their rivals. Consistent with the first possibility, Duso et al. (2006) find, for a sample of mergers and acquisitions that were analyzed by the European Commission, statistically significant positive abnormal returns for the competitors of the merging firms. 


\subsection{Methodology}

Event study techniques have been used to evaluate corporate events and the effect of regulatory changes in different industries. Hypotheses that make some prediction for firms' profits can be tested with these widely and increasingly used techniques. The theoretical foundations and the basic empirical techniques are discussed for example in Lamdin (2001), ${ }^{13}$ Roberts (1967), Cox and Portes (1998) and Markiel (2003). A crucial assumption of event studies is that all publicly available information is incorporated in stock prices, that is, the semi-strong version of the efficient market hypothesis holds. This is not the place to discuss this hypothesis, but it is a salutary caveat to remark that many of the economic implications of event studies hold to the extent that this hypothesis is valid.

The most widespread model used to predict normal returns of firm $j$ in period $t$ is the market model. Then real returns are compared to these normal returns to obtain a measure of abnormal returns (Campbell et al., 1997, and Fama et al., 1969).

$$
R_{j, t}=\alpha_{j}+\beta_{j} R_{m, t}+\varepsilon_{j, t}
$$

with $E\left(\varepsilon_{j, t}\right)=0$ and $\operatorname{Var}\left(\varepsilon_{j, t}\right)=\sigma_{\varepsilon_{j}}^{2}$

where $R_{j t}$ are the returns of firm $j$ in period $t, R_{m t}$ are the returns of a portfolio of firms representing the stock market (we use Eurofirst 300), $\alpha_{j}$ and $\beta_{j}$ are parameters and $\varepsilon_{j t}$ is an error term. To this model, one can add a dummy variable:

$$
R_{j, t}=\alpha_{j}+\beta_{j} R_{m, t}+\gamma_{j} D_{j, t}+\varepsilon_{j, t}
$$

Where $\gamma_{j}$ captures the abnormal return of action $j$ in the date of event $t$, directly estimated in the regression. One can group sets of actions to compute average abnormal returns, for examples for takeover events of a same firm or group of firms. With several firms, it iwould be possible to obtain extra information by using a system of equations (Binder, 1985):

$$
R_{1, t}=\alpha_{1}+\beta_{1} R_{m, t}+\sum_{a=1}^{A} \gamma_{1 a} F_{1, t}+v_{1}
$$

\footnotetext{
${ }^{13}$ See also Mackinlay (1997), Binder (1998), Khotari and Warner (2006) and Aktas et al. (2007).
} 


$$
R_{2, t}=\alpha_{2}+\beta_{2} R_{m, t}+\sum_{a=2}^{A} \gamma_{2 a} F_{2, t}+v_{2}
$$

$$
R_{n, t}=\alpha_{n}+\beta_{n} R_{m, t}+\sum_{a=n}^{A} \gamma_{n a} F_{n, t}+v_{n}
$$

where $v_{1} \ldots v_{n}$ are the error terms for the $n$ firms. These terms can be heteroskedastic across firms, but not correlated over time. It is also possible to introduce restrictions over coefficients, such as equality of betas, which can be tested through maximum likelihood or Wald tests.

As argued by Savickas (2003), an appropriate approach used to estimate the volatility of the conditional process of the variance, can be represented as follows:

$$
\begin{aligned}
& R_{j, t}=\alpha_{j}+\beta_{j} R_{m, t}+\gamma_{j} D_{j, t}+\eta_{j, t} \\
& \eta_{j, t} \approx N\left(0, h_{j, t}\right) \\
& h_{j, t}=a_{j}+b_{j} h_{j, t-1}+c_{j} \eta^{2}{ }_{j, t-1}+d_{j} D_{j, t}
\end{aligned}
$$

where $h_{j, t}$ is the conditional variance of the time variation and $a_{j}, b_{j}, c_{j}, d_{j}$ are the coefficients of the GARCH $(1,1)$ specification; $D_{j, t}$ dummy variable equal to 1 for the date of the event for firm $j$ and 0 otherwise. $\gamma_{j}$ captures the coefficient of the abnormal returns on the date of the announcement. The conditional variance $h_{j, t}$ provides a natural estimator of the variance of the abnormal returns.

The GARCH approach explicitly models the volatility of the returns and the possible increase of the variance that takes place when there are unforeseen events. In the estimation through a traditional approach such as OLS, there is a higher probability of rejecting the null hypothesis when this is not false (Savickas, 2003).

\subsection{Data}

The events concerning takeovers, mergers and acquisitions for each of the firms were selected from the data bases LEXIS-NEXIS and OSIRIS. The criterion that was 
used for their selection was that they had the characteristic of a "surprise" event, that is, not anticipated by the market.

The historical series of daily stocks and indices was obtained from Yahoo Finance $^{14}$ and in some cases directly through the firms (as in the case of the historical series of Hidrocantábrico stock prices; Hidrocantábrico ceased to be traded as an independent stock when it was acquired by Electricidade de Portugal). The European indices used in the estimations is Eurofirst 300.

\section{Impact of corporate change on the value of the main European energy firms}

\subsection{The Market for Corporate Control in the Energy Sector ${ }^{15}$}

Europe has seen an unprecedented crossborder mergers and acquisitions wave in the energy sectors at the beginning of the XXI century. This seems to have been in preparation or as a reaction to regulatory reform in the industry. If companies cannot influence market rules, they may try to influence industry structure. We present in this subsection some case studies that show how takeovers in energy sectors are protracted and how the setting is such that the shareholders of the target firms stand to gain much more than the shareholders of bidding firms.

\section{The Endesa Takeover Battle}

In September 2005 the Spanish firm Gas Natural made an offer for Endesa that triggered a bitter economic and political debate, because a company based in Barcelona (the second largest city in the country) was trying to take over a company based in the capital Madrid. The management team of Endesa defended its position using political and economic strategies. In 2006, an offer by E.On improved upon the one by Gas Natural, although it was also initially rejected by the management team, and triggered a reaction by the Spanish government trying to stop a surprise acquisition of control by foreign interests. This reaction included a discretional change in the rules of the elecricity regulatory agency that allowed this agency to stop a merger appealing to reasons of security of supply or national interest. In 2007, the battle finished with an Italian company, ENEL, which had the Italian state as the main shareholder, gaining

\footnotetext{
${ }^{14} \mathrm{http}: / /$ finance.yahoo.com

15 The full list of individual events on which this subsection is based can be found in García-Rendón (2010) and is available upon request.
} 
control of the company in partnership with a Spanish construction firm, apparently with the agreement of the Spanish government.

Spanish electricity firms (and especially Endesa) had been among the protagonists of a remarkable expansion process characterized by investments in Latin America. The global result of the expansion in Latin America was neutral for Endesa's shareholders, according to the event study technique, although the impact of the largest acquisition, the takeover of Chilean firm Enersis, was negative according to two studies mentioned below. Endesa also expanded in telecommunications (Retevisión, Amena, Menta, later integrated under the company name Auna), although it has recently abandoned this industry after the sale of Auna to Ono and France Telecom. ${ }^{16}$ Both in Telefónica and in Endesa there are reasons to believe that the main corporate control mechanisms did not work appropriately. There were no shareholders with a controlling stake, there was no credible takeover threat at the time (either because of public ownership at the early stages of the expansions, or because of the government's threat to use the golden share), and product market and managerial labor market competition were scarce. The takeover of Enersis, the largest privatized electricity firm in Chile, in the late 1990s, took longer and was more costly than expected, and with a negative effect on (both bidder and target) shareholder wealth. It is not clear either that Chilean consumers were better off with the takeover. On the one hand, the takeover put pressure on the Chilean regulator to improve competition conditions in electricity, by triggering a debate on vertical integration. But Endesa won the takeover battle by defeating an offer by the American firm Duke Energy, which was less willing to pay the high cost of a protracted and politicized battle, but it may well have had a better business plan for consumers.

Precise quantitative evidence on the effects of Spanish firms' expansion comes from event studies, which provide a measurement of the impact of particular events on shareholders' expectations (and, therefore, to the extent that financial markets are efficient, a quantification of the expected effect on the firm's discounted value). López Duarte and García Canal (2005) report a positive and significant effect of foreign investments of all Spanish firms (not only in the electricity sector) on shareholder value,

\footnotetext{
${ }^{16}$ Unión Fenosa is also a Spanish electricity firm with significant investments outside the energy sectors, for example in the Airports sector in Mexico, or in the engineering sector with subsidiary Soluziona. Although diversification ouside the energy sectors have been punished by investors, the participation of the same firm both in electricity and gas markets is broadly accepted as a value-creating development, due to productive efficiency gains obtained through mainly vertical integration in the provision of gas as an input in electricity generation, and also to joint offers in the retail supply of gas and electricity.
} 
but accompanied by a very high proportion, more than $45 \%$, of investment announcements with a negative impact on shareholders. Trillas (2001) concentrates on the Endesa case, with especial attention on the Enersis takeover. This study reveals a negative and significant impact for their own shareholders and for the minority shareholders of the target firm in the largest acquisition of Endesa in Latin America. However, existing event studies, either they present a too general picture, or a too narrow one, without presenting as yet a quantification of the effect on shareholders of all corporate control transactions in the overall electricity industry. The fact that the largest firms have been acquirers makes it likely that the global result will most probably not be a net gain for shareholders (given that the bidder shareholders usually obtain worse results than target shareholders), but the exact quantitative exercise remains to be done, and will probably and reasonably have to wait until the takeover wave ends. The increasing takeover threat on these large firms can more recently be a discipline mechanism for managers, who possibly will be in a learning process on how to better measure investment risks.

After the Gas Natural takeover, E.On showed interest in Endesa. E.On is the result of the merger of two large electricity firms in Germany in the late 90s, Veba and Viag. The resulting firm very soon engaged in a number of international acquisitions, such as Sydkraft in Sweden and Powergen in the United Kingdom, and merged with the dominant German gas operator, Ruhrgas. In early 2006, E.On announced its last big acquisition, a takeover over Spanish Endesa, competing with a previous takeover launched by the Spanish gas firm Gas Natural. E.On thus followed the pattern of first creating a strong national firm and next expanding internationally.

The Powergen and Endesa acquisitions were presented both as friendly or "white knight" acquisitions. Powergen and Endesa also have in common that they were both the result of privatization and had been diversifying in other industries and geographically -Powergen in the US and Endesa in Latin America.

The example of E.On is often shown to illustrate a trend towards vertically integrated global utilities focused both on gas and electricity, but abandoning investments in other industries such as telecommunications. The only significant effect of the main E.On acquisition announcements in the recent past is a positive abnormal return at the time of the Ruhrgas merger announcement. The announcement of the acquisitions of Powergen and Endesa did not have a significantly different from zero effect on shareholder value, although the sign of the abnormal return in the Endesa case 
is positive. This is consistent with the theoretical and empirical research on takeovers, which expects that shareholder gains are captured by the target firm shareholders. In contrast with the acquisition of Enersis by Endesa, however, at least the acquiring shareholders do not expect to lose from these acquisitions. Since 2000 the stock market behavior of E.On had been much better than that of Endesa. ${ }^{17}$

Since E.ON stepped in at the end of February 2006 with a bigger and better offer than that of Gas Natural, the government manoeuvred to frustrate it. E.ON was offering $€ 29.1$ billion ( $\$ 34.7$ billion) for Endesa - the biggest takeover bid in the history of the utilities industry - compared with Gas Natural's €22.5 billion cash-and-stock offer. After its own antitrust authority and the EU approved E.ON's proposal in April, the government's obstructionism intensified. Eager to thwart the deal, the government invested special powers in CNE, which is Spain's energy regulator and is controlled by a board that is close to the government. At the end of July 2006 the CNE imposed 19 conditions on E.ON's bid for Endesa, such as a commitment to invest in gastransmission networks and an obligation to keep Endesa properly capitalised. Three of the CNE's demands were very controversial. First, E.ON would have to sell the only nuclear-power plant wholly owned by Endesa. Next, it would also have to sell all of Endesa's coal-powered plants, because Spanish coal is subsidised and the government is worried that the Germans would use cheaper imports. Third, Endesa's operations on the Balearic and Canary Islands, and in northern Africa, must be divested.

After a takeover battle of more than two years, the end seemed to be near when on 1st Octubre 2007 ENEL and Acciona announced that they were in posesion of $92.06 \%$ of the shares. However, it was not until February 2009 that ENEL obtained full ownership of Endesa, after a series of discrepancies with Acciona. The control battle that had started on September 5th 2005 finished almost two and a half years later.

On July 4th 2007, the Spanish energy regulatory agency CNE approved, under twelve conditions, the takeover launched by ENEL and Acciona. The next day, the takeover was also approved by the European Commission. Between August 2005 (one month prior to the first takeover by Gas Natural) until October 2007 (when ENEL and Acciona effectively acquired $92.06 \%$ of Endesa), the value of the shares of Endesa increased in $119 \%$ (see Graph 1).

\footnotetext{
${ }^{17}$ See Trillas (2006).
} 


\section{Graph 1. Evolution of Endesa share prices}

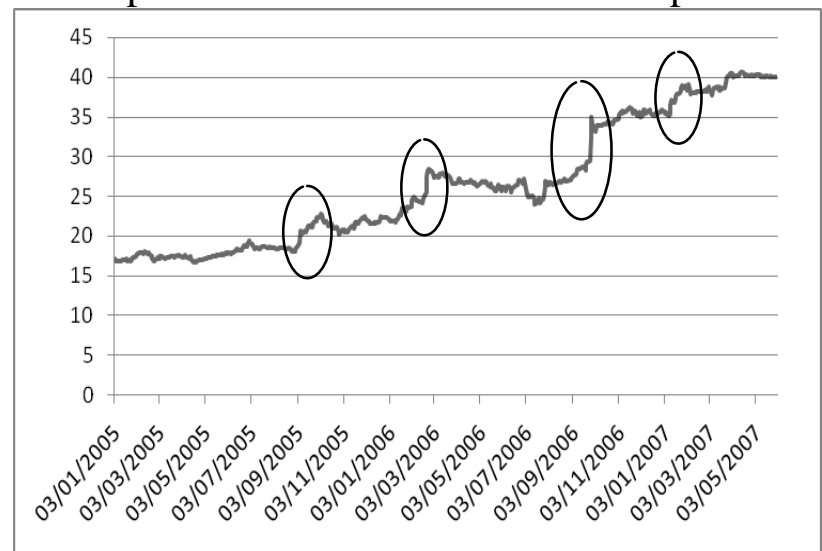

Source: Yahoo Finance.

Using the GARCH methodology suggested by Savickas (2003), the average abnormal returns for Endesa shareholders of events related to the takeover battle were $4.16 \%$. The OLS results are $2.72 \%$ (see Table 2). This is consistent with our hypothesis that target firm shareholders are winners in takeover battles. ${ }^{18}$

Table 2. Results for the Endesa and Hidrocantábrico takeovers

\begin{tabular}{lcccccc} 
& \multicolumn{3}{c}{ GARCH } & \multicolumn{3}{c}{ OLS } \\
\hline Firm & Intercept & $\begin{array}{l}\text { Event } \\
\text { Dummy }\end{array}$ & $\begin{array}{l}\text { Market } \\
\text { Returns }\end{array}$ & Intercept & $\begin{array}{l}\text { Event } \\
\text { Dummy }\end{array}$ & $\begin{array}{l}\text { Market } \\
\text { Returns }\end{array}$ \\
\hline ENDESA & 0.000 & 0.041 & 0.601 & 0.000 & 0.027 & 0.729 \\
& $(1.60)$ & $(22.42)^{*}$ & $(33.40)^{*}$ & $(0.73)$ & $(5.56)^{*}$ & $(30.33)^{*}$ \\
HIDROCAN & -0.000 & 0.031 & 0.011 & 0.001 & 0.017 & 0.058 \\
TABRICO & $(-0.27)$ & $(40.79)^{*}$ & $(0.72)$ & $(1.28)$ & $(3.43)^{*}$ & $(1.07)$ \\
\hline
\end{tabular}

$* 1 \%$ significance level.

In parentheses, t-statistic.

Sources: LEXIS-NEXIS, OSIRIS, Yahoo Finance.

\section{The Hidrocantábrico Takeover Battle}

In 2000, EnBW, a German subsidiary of the state owned French firm EDF, announced a takeover of Hidrocantábrico, the fourth largest electricity firm in Spain, which has most of its assets in the northern region of Asturias. The Spanish government reacted passing a law forbidding any foreign state-owned firm from controlling an electricity company. This law would be subsequently rejected by the European institutions. The Asturias regional government was more open to bargaining, and since the beginning showed a predisposition to lobby for the takeover in exchange for industrial and employment concessions. The takeover battle triggered by the initial EDF

\footnotetext{
${ }^{18}$ And it is consistent with a large literature: Campa and Hernando (2004), Andrade (2001), Bradley et al. (1988), Eckbo (1983).
} 
offer ended four years later, in 2004, when the state-owned Electricidade de Portugal (EDP), in partnership with a regional savings bank, Cajastur, made a final winning offer that was accepted by the shareholders of Hidrocantábrico, committing the firm to keep its headquarters in Asturias and develop a number of industrial development and employment programs.

The case of the ownership and control change in Hidrocantábrico illustrates some of the more interesting aspects in the corporate control market in Spain, namely the role of the different levels of government (European, Spanish, regional), the saving banks, the state owned firms and target firm managers. Hidrocantábrico unsuccessfully opted to buy Viesgo when Endesa put it up for sale. Besides, the takeovers of Unión Fenosa and Ferroatlántica-EnBW implied the withdrawal of other takeovers that had been launched, respectively, by the US firm Texas Utilities and the German firm RWE. Furthermore, the Spanish government lifted the veto on the political rights of foreign state owned firms in Hidrocantábrico in September 2003 after receiving a warning from the European Commission.

Hidrocantábrico was the target of five takeovers in 2000 and 2001, those launched by Texas Utilities, Unión FENOSA, Ferroatlántica-EnBW, RWE and Cajastur-EDP. That is, one US firm, two German firms (one of them with the state owned French firm EDF as the main shareholder), one Portuguese firm and one Spanish firm. The Belgian firm Electrabel also participated in the takeover contest as a minority shareholder. The winning takeover was that of Ferroatlántica-EnBW, although Cajastur and EDP stayed as minority shareholders. Eventually, EDP acquired, in a direct transaction in 2004, a share package from the rest of shareholders to reach $95 \%$ of the stock, in such a way that Hidrocantábrico became a subsidiary of EDP, with a Chairman proposed by the minority local shareholder, saving bank Cajastur. The successful foreign companies, first EnBW and next EDP, participated in the contest in alliance with local investors, with the goal of overcoming political resistance associated to the loss of control by national shareholders.

The control contest for Hidrocantábrico, the fourth largest Spanish electricity firm, lasted more than one year between 2000 and 2001, and it did not end in practice until 2004 with the assumption of total control by EDP.

One of the interesting issues in this takeover battle was that the regional government from Asturias (one of the Spanish Autonomous Communities in the North of Spain, where the company headquarters and most of its assets are located) and the 
then incumbent management team called for the takeover battle to take place, setting as condition that the firm kept its headquarters in Asturias and that the ownership change was compatible with maintaining industrial and employment objectives in the region. This illustrates that not all governments support national or regional champions in the same way. With the outcome of the battle, economic and social agents in Asturias managed to make compatible strong gains for shareholders; the entry of a strong firm with the ambition to be a key player in the forthcoming (although several times postponed) Iberian Electricity Market together with the largest Spanish electricity firms, implying consumer gains from product market competition and improved productive efficiency; and the guarantee that the new owners would cooperate with "strategic" objectives of industrial and employment policy, as interpreted by the Asturias regional government.

Between the starting point of the takeover battle and the approval of the final bid by the European Commission in March 2002, the share prices of Hidrocantábrico increased by $120 \%$ (see Graph 2).

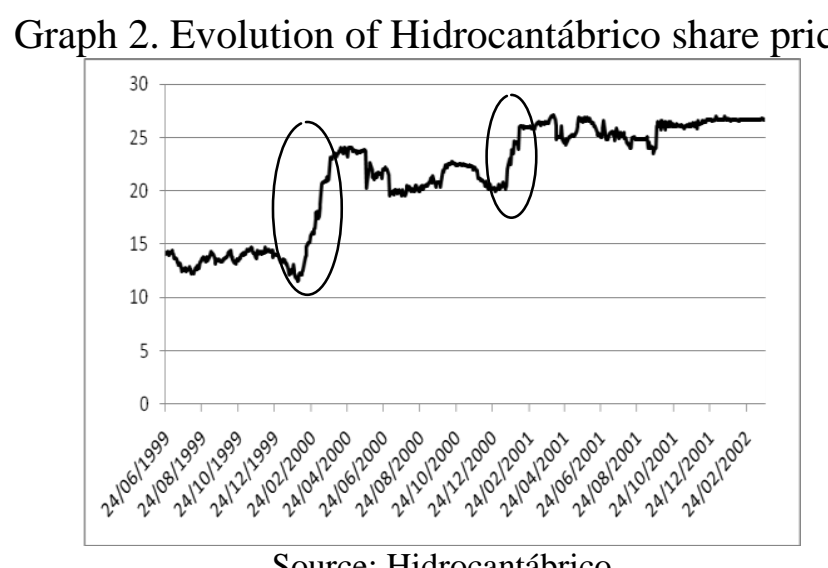

Source: Hidrocantábrico

Using the GARCH methodology, the average abnormal returns for Hidrocantábrico shareholders of events related to the takeover battle were $3.1 \%$. The OLS results are $1.7 \%$ (see Table 2). This is again consistent with our hypothesis that target firm shareholders are winners in takeover battles.

\section{Merger between Iberdrola and Scottish Power}

The process of the acquisition of Scottish Power by Iberdrola only lasted five months. Iberdrola announced its interest in the Scottish firm on November 8th, 2006, and the courts in Edimburgh resolved the last barriers for the integration of both firms 
on 23 de April, 23d, 2007. A plausible explanation of this is that market power in the British energy market is not high. This is one of the few energy markets in Europe where concentration levels are relatively low. ${ }^{19}$ This was ratified by the European Commission when it approved the transaction without conditions on February 15th, 2007. On March $2^{\text {nd }}$ of the same year, the parties obtained the last regulatory approval by the Public Utilities Commission of the State of New York in the US, which was needed given that both merging firms had assets in the American market.

The surprise announcement of the acquisition on November $8^{\text {th }} 2006$ was associated to a 3\% abnormal return, computed both with the GARCH and OLS methodologies. If we compute the impact on shareholders between one month before the takeover, October 2006, and April 2007, when the acquisition is finally authorized, the share price increased in $20 \%$ (see Graph 3 ).

Compared with the much higher increase of the value of Endesa and Hidrocantábrico during their takeover battles, in this case the value increase is substantially lower. One possible explanation is that these Spanish firms operated in a context of higher market power, with larger rents to be captured from reducing the number of firms. Campa and Hernando (2004) find that the announcements of mergers and acquisitions for firms in industries that had previously been under strong regulatory controls, obtain comparatively lower abnormal returns than when regulatory controls are less strict.

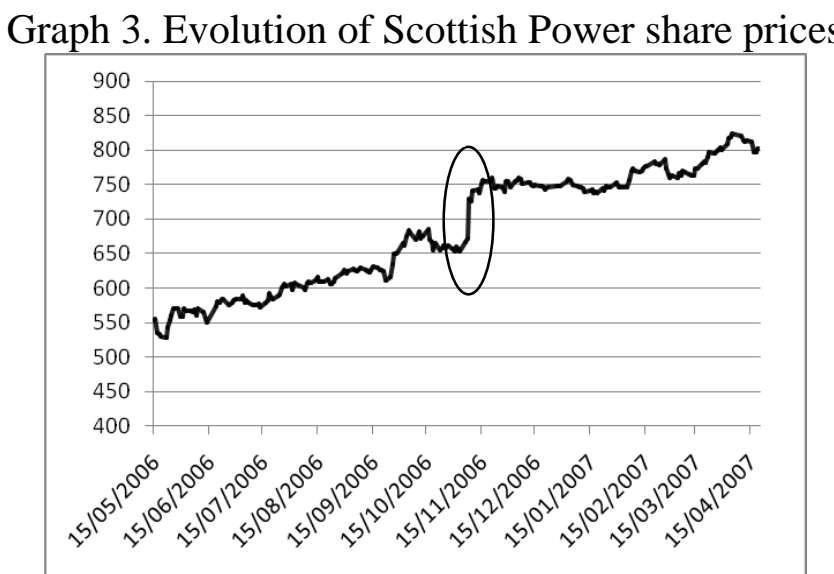

Source: Yahoo Finance.

\footnotetext{
${ }^{19}$ For example the HHI for the UK after 1999 has been below 1000 points (Mattes et al., 2005). The thresholds established by the US and the EU define a market as highly concentrated at 1800 and 2000 respectively. A market with a HHI below 1000 is defined as non-concentrated.
} 


\section{Effects of the takeovers on competitors' returns}

Table 3 shows the effect that the Endesa and Hidrocantábrico takeover announcements had on their closest competitors in the Spanish electricity pool. In all cases, competitors experience statistically significant positive abnormal returns. For example, on occasion of the Endesa takeovers, competitors Iberdrola and Unión Fenosa experienced abnormal returns of $2.1 \%$ and $1 \%$, respectively (both with GARCH and OLS). On occasion of the Hidrocantábrico takeovers, competitors Endesa, Iberdrola and Unión Fenosa experience on average abnormal returns of $1.7 \%, 1.4 \%$ and $0.9 \%$, using GARCH, and 1.2\%, 1.5\% and 0.4\%, using OLS. Unión Fenosa's abnormal returns when the Hidrocantábrico takeovers are announced are not statistically significant, but this was at the time a small competitor. Overall, the results suggest that increased concentration derives into higher market power for all the firms in the market, along the lines of Eckbo (1983) and Aktas et al. (2006).

On occasion of the takeover of Scottish Power by Iberdrola, in contrast, Brittish competitors Centrica and National Power experience non-significant positive abnormal returns of $0.9 \%$ and $0.4 \%$, respectively, both with models GARCH and OLS. A possible explanation is that the Brittish market was characterized by a lower level of market power than the Spanish electricity market. Whereas the Herfindahl-Hirschman (HHI) index in the early years of the XXI Century was below 1000 in the UK, it was between 1500 and 1800 in Spain (Mattes, 2005). As explained by Duso et al. (2006) a positive reaction by competitors could be explained by the takeovers revealing information about potential efficiency gains in the industry as a whole. However, the fact that competitors react differently in markets with different degrees of concentration, suggests that market power is a more plausible explanation. 
Table 3. Takeover Effects on Competitors

\begin{tabular}{lcccccc} 
& \multicolumn{3}{c}{ GARCH } & \multicolumn{3}{c}{ OLS } \\
\hline Company & Intercept & $\begin{array}{l}\text { Event } \\
\text { Dummy }\end{array}$ & $\begin{array}{l}\text { Market } \\
\text { Returns }\end{array}$ & Intercept & $\begin{array}{l}\text { Event } \\
\text { Dummy }\end{array}$ & $\begin{array}{c}\text { Market } \\
\text { Returns }\end{array}$ \\
\hline $\begin{array}{l}\text { Endesa } \\
\text { takeovers effect }\end{array}$ & & & & & & \\
on: & & & & & & \\
$\quad$ Iberdrola & 0.000 & 0.021 & 0.443 & 0.001 & 0.021 & 0.336 \\
& $(1.32)$ & $(8.63)^{*}$ & $(24.61)^{*}$ & $(2.01)^{*}$ & $(4.73)^{*}$ & $(14.41)^{*}$ \\
Unión Fenosa & 0.000 & 0.010 & 0.535 & 0.000 & 0.010 & 0.525 \\
& $(2.12)^{*}$ & $(2.83)^{*}$ & $(23.36)^{*}$ & $(1.08)$ & $(1.99)$ & $(18.48)^{*}$ \\
\hline Hidrocantábrico & & & & & & \\
takeovers effect & & & & & & \\
on: & & & & & & \\
Endesa & -0.001 & 0.017 & 0.443 & -0.001 & 0.012 & 0.421 \\
Iberdrola & $(-0.83)$ & $(7.11)^{*}$ & $(9.63)^{*}$ & $(-0.84)$ & $(2.75)^{*}$ & $(8.72)^{*}$ \\
& -0.0002 & 0.014 & 0.201 & 0.000 & 0.015 & 0.205 \\
Unión Fenosa & $(-0.41)$ & $(3.97)^{*}$ & $(5.09)^{*}$ & $(0.05)$ & $(3.34)^{*}$ & $(4.14)^{*}$ \\
& 0.000 & 0.009 & 0.232 & -0.001 & 0.004 & 0.252 \\
& $(0.03)$ & $(1.16)$ & $(4.82)^{*}$ & $(-0.05)$ & $(0.83)$ & $(4.43)^{*}$ \\
\hline
\end{tabular}

* Significant at $1 \%$. T-values in parentheses.

Sources: LEXIS-NEXIS, OSIRIS and Yahoo Finance.

\subsection{Mergers and Acquisitions of European Energy Firms between 2000 and 2007}

In this sub-section, we analyze the impact of 40 events $^{20}$ related to mergers and acquisitions by 11 of the most important energy firms in Europe. The abnormal returns of these firms' shares for these events are computed using OLS and GARCH. These 11 firms are: two German (RWE and E.ON), two Italiandos (ENI and ENEL), one French (Suez), four Spanish (Endesa, Gas Natural, Iberdrola and Unión Fenosa), one Swedish (Vattenfall) and one Portuguese (EDP). These firms were quoted in the stock markets between 2001 and 2007. We collected surprise mergers and acquisitions events (summarized in Table 4) for these companies using databases LEXIS-NEXIS and OSIRIS, between July 10th 2001 and May 31st, 2007.

\footnotetext{
${ }^{20}$ As in the previous section, three observations are taken into account for every event: the day before, the anouncement day, and the day after the announcement.
} 
Tabla 4 Mergers and Acquisitions Events

ENDESA SA (Spain)

\begin{tabular}{ll}
\hline Date & Description \\
\hline 28-Feb-07 & $\begin{array}{l}\text { ENEL buys } 9.99 \% \text { of shares in Endesa, to start competing with E.On for the control of the firm } \\
\text { 25-Sep-06 }\end{array}$ \\
Acciona buys 10\% of Endesa for 32 euros per share \\
E.ON offers to acquire 100\% of Endesa SA for 27.5 euros per sharea. The transaction was later \\
cancelled \\
$\begin{array}{l}\text { Gas Natural launches a takeover for 100\% of Endesa SA for 21.3 euros per share. The transaction } \\
\text { was later cancelled }\end{array}$ \\
\hline
\end{tabular}

\section{EDP (Portugal)}

18-May-07 HC Energia (subsidiary of EDP) acquires 9.39\% NaturGas - Sociedad de Gas de Euskadi SA

26-Oct-06 EDP exercises his call option to acquire 100\% of OPTEP-SGPS SA. The transaction was completed on November $2^{\text {nd }}, 2006$

04-Jun-03 EDP is interested in acquiring 75\% of Turbogas Productora Energética SA. The transaction was cancelled on November, $12^{\text {th }}, 2003$

31-Jul-02 EDP shows interest in acquiring $10 \%$ of Turbogas Productora Energética SA. The transaction was completed on September, $27^{\text {th }}, 2002$

\begin{tabular}{|c|c|}
\hline \multicolumn{2}{|c|}{ ENI SPA (Italy) } \\
\hline 03-Abr-07 & ENI Angola Exploration BV (Subsidiary of ENI) agrees to acquire $13.6 \%$ of Angola LNG Limited \\
\hline 02-Dic-04 & $\begin{array}{l}\text { Distribuidora de Gas Cuyana SA transfers } 6.84 \% \text { of its shares to ENI, while Inversora de Gas Cuyana } \\
\text { SA transfers } 76 \% \text { of its stake in the same firm }\end{array}$ \\
\hline 18-Jul-02 & Agip Petroli SpA (subsidiary of ENI) acquires $100 \%$ of retail networks of Italys Tam \\
\hline 07-Nov-01 & SNAM International BV (subsidiary of ENI) acquires $40 \%$ of Trans-Austria-Gasleitung GmbH \\
\hline \multicolumn{2}{|c|}{ ENEL SPA (Italy) } \\
\hline 23-Mar-07 & ENEL and Acciona launch a takeover on Endesa SA for 41.3 euros per share \\
\hline 17-Feb-05 & ENEL signs a contract for the purchase of Slovenske Elektrarne \\
\hline $11-$ Oct-02 & $\begin{array}{l}\text { ENEL presents a prelimiary offer to acquire a share in Depa from Greece. It was cancelled on } 15 \text { th } \\
\text { April } 2003\end{array}$ \\
\hline \multicolumn{2}{|c|}{ E.ON (Germany) } \\
\hline 11-Jul-06 & E.ON could buy $46.6 \%$ of Jihoceska Plynarenska AS \\
\hline 22-Feb-06 & $\begin{array}{l}\text { E.ON reaches an agreement with RWE to Exchange its shares in Check and Hungarian gas } \\
\text { distributors, where E.ON buys } 46.4 \% \text { of Jihoceska Plynarenska AS, } 25 \% \text { of Prazska Plynarenska } \\
\text { Holding and } 49.3 \% \text { of Prazska Plynarenska }\end{array}$ \\
\hline 21-Feb-06 & E.ON announces a takeover on Endesa SA for 27.5 euros per share. \\
\hline 16-Feb-04 & E.ON acquires a share of Graninge $\mathrm{AB}$ \\
\hline 31-Jul-02 & $\begin{array}{l}\text { E.ON Energie AG (subsidiary of E.ON) acquires } 25.5 \% \text { of Elektrizitaetswerk Minden-Ravensberg } \\
\text { GMBH }\end{array}$ \\
\hline \multicolumn{2}{|c|}{ Gas Natural SDG SA (Spain) } \\
\hline 05-Sep-05 & $\begin{array}{l}\text { Gas Natural announces a takeover to acquire } 100 \% \text { of Endesa SA for } 21.3 \text { euros per share, which was } \\
\text { later cancelled }\end{array}$ \\
\hline 13-Jan-04 & Gas Natural formalizes the purchase of Brancato \\
\hline 18-Jun-03 & Gas Natural acquires a share of $35 \%$ of Depa \\
\hline 16-May-02 & In the prcess of privatization Gas Natural SDG SA sells $23 \%$ of its shares \\
\hline \multicolumn{2}{|c|}{ IBERDROLA (Spain) } \\
\hline 08-Nov-06 & Iberdrola ponders a merger with Scottish Power, which would subsequently be approved \\
\hline 27-Sep-06 & Construction group ACS acquires $6.31 \%$ in Iberdrola SA \\
\hline 10-Mar-03 & $\begin{array}{l}\text { Gas Natural launches a takeover on Iberdrola SA. On April, 30th, } 2003 \text { the energy regulatory agency } \\
\text { CNE rejected the offer. }\end{array}$ \\
\hline \multicolumn{2}{|c|}{$R W E A G($ Germany) } \\
\hline 31-Dec-03 & RWE announces its willingness to acquire $49 \%$ of Slovak Power Utility VSE \\
\hline 19-Sep-03 & $\begin{array}{l}\text { RWE announces the purchase of } 24 \% \text { of Ibbenbueren Coal-Fired Power Plant, increasing its share to } \\
76 \% \text {. The transaction was completed on December, } 31 \text { st, } 2003\end{array}$ \\
\hline 19-Nov-02 & Gaz De France starts negotiations with RWE Trading Direct Ltd (subsidiary of RWE) to buy it \\
\hline 18-Nov-02 & $\begin{array}{l}\text { RWE reaches an agreement to acquire } 20 \% \text { of Wuppertaler Stadtwerke AG. The transaction is } \\
\text { complete don November 5th, } 2003\end{array}$ \\
\hline
\end{tabular}


Suez (France)

24-Feb-06 Gas de France and Suez SA announce a friendly merger.

09-Ago-05 Suez announces the acquisition of $49.9 \%$ of Electrabel SA. The transaction is completed on December $13^{\text {th }}, 2005$

10-Jun-02 Electrabel SA (subsidiary of Suez) acquires 11.4\% of Compagnie Nationale du Rhone

19-Sep-01 Tractebel SA (subsidiary of Suez) acquires 95\% of Baymina Energy Inc

12-Sep-01 Tractebel SA (subsidiary of Suez) acquires $80 \%$ of Houay Ho Power Co Ltd

\begin{tabular}{|c|c|}
\hline \multicolumn{2}{|c|}{ Unión Fenosa (Spain) } \\
\hline $10-$ Oct-02 & Banco Santander Central Hispano acquires $4.3 \%$ of Unión Fenosa SA \\
\hline 25-Jul-01 & Unión Eléctrica Fenosa (UEF) acquires 25\% of Unión Fenosa Generación SA \\
\hline \multicolumn{2}{|c|}{ Vattenfall Europe AG (Suecia) } \\
\hline 03-Dec-01 & Vattenfall buys German firm Bewag \\
\hline 12-Nov-01 & $\begin{array}{l}\text { After the likely merger of Vattenfall, HEW, Veag and Laubag an important energy group would } \\
\text { emerge in Germany }\end{array}$ \\
\hline
\end{tabular}

Sources: LEXIS-NEXIS and OSIRIS.

GARCH and OLS individual regressions for each firm (see Table 5) show two results $^{21}$ (consistently with Bradley et al., 1988, and Andrade et al., 2001):

1) The firms that were mostly involved in selling transactions (Endesa and Iberdrola) experience statistically significant positive abnormal returns at the $1 \%$ level with both methods. For Endesa these returns are 3.7\% using GARCH and $2.7 \%$ using OLS; while for Iberdrola they are $1.5 \%$ and $1.2 \%$ respectively.

2) The firms that were mostly involved in buying transactions mostly experience statistically significant negative abnormal returns. Only three of them experienced the opposite sign: Suez and EDP both with GARCH and OLS, and E.ON only with GARCH.

\footnotetext{
${ }^{21}$ These results are qualitatively the same using pooled OLS and SURE regressions for all firms, but the tests reveal that the system of equations does not significantly improve in efficiency relative to the individual firm regressions (see García-Rendón, 2010).
} 
Table 5. Abnormal Returns for Mergers \& Acquisitions Events:

\begin{tabular}{|c|c|c|c|c|c|c|}
\hline & & GARCH & & & OLS & \\
\hline Company & Intercept & $\begin{array}{c}\text { Event } \\
\text { Dummy }\end{array}$ & $\begin{array}{l}\text { Market } \\
\text { Returns }\end{array}$ & Intercept & $\begin{array}{c}\text { Event } \\
\text { Dummy }\end{array}$ & $\begin{array}{l}\text { Market } \\
\text { Returns }\end{array}$ \\
\hline EDP & $\begin{array}{c}0.000320 \\
(1.03)\end{array}$ & $\begin{array}{c}0.016293 \\
(6.65)^{*}\end{array}$ & $\begin{array}{c}0.394865 \\
(14.38)^{*}\end{array}$ & $\begin{array}{c}0.000139 \\
(0.40)\end{array}$ & $\begin{array}{c}0.014469 \\
(3.59)^{*}\end{array}$ & $\begin{array}{c}0.394735 \\
(13.76)^{*}\end{array}$ \\
\hline Endesa & $\begin{array}{c}0.000303 \\
(1.30)\end{array}$ & $\begin{array}{l}0.036562 \\
(25.82)^{*}\end{array}$ & $\begin{array}{l}0.739962 \\
(33.05)^{*}\end{array}$ & $\begin{array}{c}0.000170 \\
(0.57)\end{array}$ & $\begin{array}{c}0.027430^{*} \\
(8.47)^{*}\end{array}$ & $\begin{array}{l}0.851247 \\
(35.33)^{*}\end{array}$ \\
\hline Enel & $\begin{array}{c}3.11 \mathrm{E}-05 \\
(0.12)\end{array}$ & $\begin{array}{c}-0.008529 \\
(-2.11)^{*}\end{array}$ & $\begin{array}{c}0.599324 \\
(25.63)^{*}\end{array}$ & $\begin{array}{c}0.000120 \\
(0.38)\end{array}$ & $\begin{array}{c}-0.012259 \\
(-2,86)^{*}\end{array}$ & $\begin{array}{c}0.654730 \\
(26,89)^{*}\end{array}$ \\
\hline Eni & $\begin{array}{c}0.000299 \\
(1.29)\end{array}$ & $\begin{array}{c}-0.009441 \\
(-3.03)^{*}\end{array}$ & $\begin{array}{c}0.780516 \\
(32.05)^{*}\end{array}$ & $\begin{array}{c}0.000371 \\
(1.32)\end{array}$ & $\begin{array}{c}-0.010498 \\
(-3.26)^{*}\end{array}$ & $\begin{array}{c}0.765360 \\
(31.89)^{*}\end{array}$ \\
\hline E.ON & $\begin{array}{c}-3.94 \mathrm{E}-05 \\
(-0.13)\end{array}$ & $\begin{array}{c}0.001085 \\
(0.48)\end{array}$ & $\begin{array}{c}1.001965 \\
(55.38)^{*}\end{array}$ & $\begin{array}{c}0.000458 \\
(0.76)\end{array}$ & $\begin{array}{c}-0.014189 \\
(-2.13)^{*}\end{array}$ & $\begin{array}{c}0.980839 \\
(19.86)^{*}\end{array}$ \\
\hline $\begin{array}{l}\text { Gas } \\
\text { Natural }\end{array}$ & $\begin{array}{c}0.000490 \\
(2.15)\end{array}$ & $\begin{array}{c}-0.011407 \\
(-7.22)^{*}\end{array}$ & $\begin{array}{c}0.592433 \\
(25.91)^{*}\end{array}$ & $\begin{array}{c}0.000646 \\
(1.96)\end{array}$ & $\begin{array}{c}-0.014767 \\
(-4.36)^{*}\end{array}$ & $\begin{array}{c}0.518015 \\
(19.07)^{*}\end{array}$ \\
\hline Iberdrola & $\begin{array}{c}0.000308 \\
(1.59)\end{array}$ & $\begin{array}{c}0.014780 \\
(7.94)^{*}\end{array}$ & $\begin{array}{l}0.464185 \\
(24.63)^{*}\end{array}$ & $\begin{array}{c}0.000618 \\
(2.29) *\end{array}$ & $\begin{array}{c}0.012074 \\
(3.71)^{*}\end{array}$ & $\begin{array}{c}0.365580 \\
(16.53)^{*}\end{array}$ \\
\hline RWE & $\begin{array}{c}0.000598 \\
(2.01)^{*}\end{array}$ & $\begin{array}{c}-0.014297 \\
(-1.50)\end{array}$ & $\begin{array}{c}0.861462 \\
(30.69)^{*}\end{array}$ & $\begin{array}{c}0.000321 \\
(0.80)\end{array}$ & $\begin{array}{c}-0.014954 \\
(-2.37)^{*}\end{array}$ & $\begin{array}{c}0.849849 \\
(25.59)^{*}\end{array}$ \\
\hline Suez & $\begin{array}{c}0.000637 \\
(1.72)\end{array}$ & $\begin{array}{c}0.018159 \\
(6.06)^{*}\end{array}$ & $\begin{array}{c}0.302737 \\
(7.01)^{*}\end{array}$ & $\begin{array}{c}-0.000108 \\
(-0.16)\end{array}$ & $\begin{array}{c}0.013766 \\
(2.08)^{*}\end{array}$ & $\begin{array}{c}0.331980 \\
(6.50)^{*}\end{array}$ \\
\hline $\begin{array}{l}\text { Unión } \\
\text { Fenosa }\end{array}$ & $\begin{array}{c}0.000661 \\
(2.75)^{*}\end{array}$ & $\begin{array}{c}-0.027376 \\
(-9.99)^{*}\end{array}$ & $\begin{array}{c}0.568988 \\
(23.91)^{*}\end{array}$ & $\begin{array}{c}0.000560 \\
(1.61)\end{array}$ & $\begin{array}{c}-0.022328 \\
(-4.08)^{*}\end{array}$ & $\begin{array}{c}0.583990 \\
(20.24)^{*}\end{array}$ \\
\hline Vattenfall & $\begin{array}{c}-0.000956 \\
(-3.97)^{*}\end{array}$ & $\begin{array}{c}-0.036767 \\
(-2.04)^{*}\end{array}$ & $\begin{array}{c}0.089242 \\
(3.18)^{*}\end{array}$ & $\begin{array}{c}0.000342 \\
(0.48)\end{array}$ & $\begin{array}{c}-0.039203 \\
(-1.83)\end{array}$ & $\begin{array}{c}0.054178 \\
(0.83)\end{array}$ \\
\hline
\end{tabular}

* $1 \%$ significance level.

t-statistics in parentheses.

Data sources: LEXIS-NEXIS, OSIRIS and Yahoo Finance.

\section{Concluding Comments: Competition Policy, National Champions and Corporate Control}

Case studies and econometric evidence presented in this paper, based on the experience of European countries, suggest that takeovers in the energy sectors i) tend to coincide with regulatory reform; ii) are very costly for buying firms; iii) generate significant gains for target shareholders; and iv) depend on the degree of (product) market power in terms of the impact on competitors and the shareholders gains to be made in the market for corporate control.

Takeovers in industries that are regulated or subject to regulatory reform are costly and protracted because these sectors are usually politicized, and governments try to intervene in them at least for two reasons: to promote a variety of public or political objectives (which can be of industrial or labor policy, or more recently of security of supply in energy sectors, or promotion of national inputs); and (relatedly) to promote national champions in international markets (Sinn, 2003, ch. 8). Golden shares and 
restrictions on foreign ownership are some of the forms that politicization may take. ${ }^{22}$ The trend of operators becoming subsidiaries of large multi-national firms has triggered the prediction by some experts that in a not so distant future there will only be two or three large European companies that will share the European electricity market. ${ }^{23}$ If a small number of firms end up facing each other in all countries, it must be remembered that multi-market contact is one of the factors facilitating collusion, so that instruments must be developed at the supranational level to pay attention to this phenomenon. The fact that, in practice, the real market does not yet have a continental scale (due to lack of transmission capacity and other constraints) does not imply that anti-trust policy should not be used, and that the laws supporting a unified capital market across the European Union should not be implemented.

European Union laws on anti-trust policy do not distinguish between public and private capital, and many national governments, with the resistance of the European Commission, the executive body in Brussels, try to stop the main companies from being bought by foreign operators. Strategies of defending the ownership of firms against foreign (often but not always state-owned) firms, in order to have any likelihood of overcoming the resistance of the European Commission, should better be based in principles that are recognized by the European norms, such as restrictions on State aid, or predatory behavior. Several studies have analyzed the incentives of state-owned firms to adopt anti-competitive behaviour, but it is difficult to state that the assumptions under which dominant state-owned firms in one particular country can abuse their dominant position, can be applied to partially privatized firms that operate in other countries. ${ }^{24}$ Managers of partially privatized firms have a fiduciary duty to minority shareholders, which implies that they cannot depart from the profit maximization objective, which makes predatory behavior very unlikely. Foreign firms that are dominant in their original country are actually a guarantee that consumers will have credible rivals among

\footnotetext{
${ }^{22}$ In May 2006 the Spanish government repealed the golden shares regime, by which it kept to itself the option of vetoing control transactions on privatized firms. This instrument was available at the time only in Endesa and Telefónica, and had been in place for more than ten years (in the UK, the golden shares on electricity distribution firms were in place during five years, and when it expired in 1995, this triggered a takeover wave that changed the ownership of all involved firms). In 1999 the Spanish government introduced a law by which the political rights of firms dominated by foreign status were restricted. This law was directed at preventing French firm Electricité de France (EDF) from taking control, through its German subsidiary EnBW, of Spanish firm Hidrocantábrico. That is, as opposed to golden shares, this restriction vetoed not only changes in former state-owned firms, but also in those that had always been in the hands of the public sector.

${ }^{23}$ See Glachant and Finnon, eds. (2003).

${ }^{24}$ On the role of state owned firms in competitive environments, see Geddes, ed. (2004).
} 
which to choose. ${ }^{25}$ What should worry European authorities is that, if anti-trust laws in the electricity industry are not harmonized, some operators may achieve competitive advantages from implicit subsidies in their local markets, with the consequence that the operators that end up giving service to consumers are not the most efficient, but those that are better protected at home.

From the point of view of regulation and anti-trust, the diversified nature of firms is more problematic. To the extent that in a particular country (that is mostly the case of Spain) the dominant regulatory practice is rate of return or cost-plus regulation, and there is no incentive regulation, firms are interested in practicing accounting and managerial cross subsidies, that is, allocating high costs and relatively less able managers to segments where it is known that costs will be reimbursed no matter their level.

An interesting feature of the takeovers of Hidrocantábrico and Endesa examined above is that the regulatory game conditioned the nature and identity of the firms that eventually resulted from the takeover battles. In Hidrocantábrico, eventually the winning bidder was Electricidade de Portugal in coalition with a regional savings bank (Cajastur) partially controlled by the Asturias regional government. In the Endesa takeovers some years later, Enel of Italy, with the Italian state as the largest bidder, won the contest against E.On after forming a coalition with the Spanish construction company Acciona. As the examples suggest, there is a risk that a disproportionate amount of Type I errors will occur: some good mergers will not be authorized. There is then a trade off between the different expertise of several regulators. Wolak (2007) argues that "few mergers involving generation unit owners in wholesale electricity markets will be able to survive this multi-stage, federal and state antitrust and regulatory approval process and still provide value to the shareholders of the merged companies. The public benefit standard applied by most public utility commissions provides state governments with a substantial ability to extract financial concessions from the merging parties that may cause the merging parties to terminate potentially beneficial mergers." This raises the risk not only of efficient mergers not happening, but also of inefficient

\footnotetext{
${ }^{25}$ This argument has finally been reluctantly accepted in Spain when it involves non-dominant firms in Spain. In telecommunications, the Spanish government did not stop the sale of cellular phone operator Amena to France Telecom or the entry of France Telecom in broadband through Wanadoo. In electricity, the government (eventually) allowed the control of Hidrocantábrico by EDP and Viesgo by Enel (see Section 3 above).
} 
firms winning in some takeover battles: ${ }^{26}$ if winning takeover battles is costly and protracted, it will not be the firms that are best at producing electricity that win, but rather the best at playing the political game, or the ones able and willing to foot the bill of these protracted processes, such as firms with bad governance or public ownership.

A merger or acquisition (especially if it takes the form of a takeover) changes the objective function of policy makers because more light is projected into the industry, consumers and other stakeholders mobilize and this has a well documented impact on the potential (lower) wealth gains to be extracted from the transaction. The existing literature shows that mergers in regulated industries take longer to be completed and show a lower takeover success ratio than in other industries; there is also clear evidence that deregulation is ususally accompanied by a takeover wave. There is a small literature on the optimal allocation of merger authority in the vertical chain of government (see Trillas, 2009). This literature focuses on the role of jurisdictional externalities in terms of the effect of a merger on the surplus that is captured by foreign consumers and the impact on foreign competitors, in a framework where a merger authority maximizes some combination of the surplus of national consumers and producers. There is no formal work to my knowledge on the role of regulatory authorities or on how to judge a merger from the point of view of it making more or less difficult the role of regulators when there are jurisdictional externalities. ${ }^{27}$

\section{Bibliography}

Aktas, N., de Bodt, E., and J. G. Cousin (2007) "Event Studies with a Contaminated Estimation Period". Journal of Corporate Finance, Vol. 13, p. 129-145.

Andrade, G., M. Mitchell and E. Stafford (2001) "New Evidence and Perspectives on Mergers". Journal of Economics Perspectives, Vol. 15, Issue 2, p. 103-120.

Binder, J.J. (1985) "Measuring the Effects of Regulation with Stock Price Data". The RAND Journal of Economics, Vol. 16, Issue 2, p. 167-183.

\footnotetext{
${ }^{26}$ See Singh (1992) for an analysis of the various inefficiencies that may affect the market for corporate control.

${ }^{27}$ Two North American merger cases involving different institutional characteristics in the vertical or horizontal dimension of government also illustrate the likely consequences of overlapping merger authority: Pacificorp and Utah Power \& Light Company (Stalon and Lock, 1990, p. 470); and the PSEGExelon merger (Wolak, 2007).
} 
Binder, J.J. (1998) “The Event Study Methodology Since 1969”. Review of Quantitative Finance and Accounting, Vol. 11, p. 111-137.

Bradley, M., Desai, A., Kim, E.M. (1988) "Synergistic Gains from Corporate Acquisitions and Their Division Between the Stockholders of Target and Acquiring Firms". Journal of Financial Economics, Vol. 21, p. 3-40.

Campa, J. and Hernando, I. (2004) "Shareholder value creation in European M\&As". European Financial Management, vol. 10, Issue 1, p. 47-81.

Campbell, J.Y., A.W., Lo, and A.C. MacKinlay (1997) The Econometrics of Financial Markets. Princeton University Press.

Codognet, M., J. Glachant, F. Léveque and M. Plagnet (2002) "Mergers and Acquisitions in the Privatized Electricity Sector". Cases and Patterns. CERNA.

Cox, A.J. and J. Portes (1998) "Mergers in Regulated Industries: the Uses and Abuses of Event Studies". Journal of Regulatory Economics, Vol. 14, p. 281-304.

Duso, T., K. Gugler and B. Yurtoglu (2006) "Is the Event Study Methodology Useful for Merger Analysis? A Comparison of Stock Market and Accounting Data". ISSN Nr. 0722 - 6748. SOCIAL Science Research Center Berlin.

Eckbo, B. P. (1983) “Horizontal Mergers, Collusion, and Stockholder Wealth". Journal of Financial Economics, Vol. 11, p. 241-273.

European Commission (2007), DG Competition Report on Energy Sector Inquiry, Brussels.

Fama, E.F., L. Fisher, M. Jensen and R. Roll (1969) "The Adjustment of Stock Prices to New Information”. International Economic Review, Vol. 10, p. 1-21.

García-Rendón, J.J (2010), Tres Ensayos sobre Funcionamiento de Mercados Energéticos, PhD Thesis, UAB.

Geddes, R.R. (2004) ed., Competing with the Government. Anticompetitive Behavior and Public Enterprises. Hoover Press.

Gerpott, T. and N. Jakoppin (2007) "Firm and Target Country Characteristics as Factors Explaining Wealth Creation from International Expansion Moves of Mobile Network Operators". Telecommunications Policy, Vol. 3, p. 72-92.

Glachant, J. and D. Finon (ed.) (2003) Competition in European Electricity Markets. A Cross-Country Comparison. Cheltenham, UK.

Glachant, Jean-Michel and François Lévêque (editores) (2009) Electricity Reform In Europe Towards a Single Energy Market. Edward Elgar.

Green, R. (2006) "Electricity Liberalisation in Europe-How Competitive Will it Be?". Energy Policy, Vol. 34, p. 2532-2541. 
Haas, R., J.M. Glachant, H. Auer, N. Keseric, Y. Pérez (2006), Competition in the Continental European Electricity Market: Despair or Work in Progress, in Shioshansi, F.P. and W. Pfaffenberger, eds., Electricity Market Reform. An International Perspective. Elsevier.

Jensen, M. C., (1993) "The Modern Industrial Revolution and the Challenge to Internal Control Systems”. Journal of Finance, Vol. 48, p. 831-880.

Khotari, S. P. Y J. Warner (2006) "Econometrics of Event Studies". In: Handbook of Corporate Finance: Empirical Corporate Finance, Forthcoming in B. Espen Eckbo (ed.), Volume A (Handbooks in Finance Series, Elsevier/North-Holland), Ch. 1.

Lamdin, D. (2001) "Implementing and Interpreting Event Studies of Regulatory Changes". Journal of Economics and Business, Vol. 53, p. 171-83.

MacKinlay, A.C. (1997) "Event Studies in Economics and Finance". Journal of Economic Literature, Vol. 35, p. 13-39.

Markiel, B. (2003) "The Efficient Market Hyphotesis and its Critics". Journal of Economic Perspectives, Vol. 17, Issue 1, p. 59-82.

Matthes, F., s. Poetzsch and K. Grashoft (2005) "Power Generation Market Concentration in Europe 1996-2004. An Empirical Analisys". Institute For Applied Ecology, Öko-Institut e.V. September.

Mitchell, M. L., and J. H. Mulherin (1996) "The Impact of Industry Shocks onTakeover and Restructuring Activity". Journal of Financial Economics, Vol. 41, Issue 2, p. 193229.

Ravenscraft, D. J. (1987) "The 1980s Merger Wave: An Industrial Organization Perspective”. The Merger Boom, editado por Lynn E. Brown and Eric S. Rosengren. Federal Reserve Bank of Boston, Boston, MA.

Roberts, H., (1967) "Statistical Versus Clinical Prediction of the Stock Market" unpublished manuscript, University of Chicago, Centre for research on security prices.

Savickas, R. (2003) "Event-Induced Volatility and Tests for Abnormal Performance". Journal of Financial Research Vol. 16, p. 165-178.

Singh, A. (1992), Corporate Takeovers, in New Palgrave Dictionary of Money and Finance.

Sinn, H.-W. (2003), The New Systems Competition, Blackwell Publiching.

Stalon, C.G.; Lock, R.H.J.H. (1990), State-Federal Relations in the Economic Regulation of Energy, Yale Journal on Regulation, 7: 427-497.

Tirole, J. (2006) The Theory of Corporate Finance, Princeton University Press. 
Trillas, F. (2000), Privatized Utilities: Regulatory Reform and Corporate Control, PhD Thesis, European University Institute.

Trillas, F. (2001) "The Takeover of Enersis: the Control of Privatized Utilities". Utilities Policy, Vol. 10, p. 25-45.

Trillas, F. (2006) "El Control Corporativo en la Industria Eléctrica". Cap. 19, Energía: del Monopolio al Mercado. CNE: Diez Años en Perspectiva, edited by José Luis García Delgado and Juan Carlos Jiménez, páginas 507-531. Madrid: Thomson Civitas.

Trillas, F. (2009) "Electricity and Telecoms Reforms in the EU: Insights from the Economics of Federalism. UAB and SP-SP Center, IESE.

Weston, J.F., K.S. Chung y J.A. Siu (2003) Takeovers, Restructuring and Corporate Governance. 2 ed, New York.

Weston, J. F., Kwang S. Chung y Susan E. Hoag (1990) Mergers, restructuring, and corporate control. Prentice Hall, Englewood Cliffs, NJ.

Wolak (2007), Merger Analysis in Restructured Electricity Supply Industries: The Proposed PSEG and Exelon Merger (2006), paper presented at POWER Conference, Berkeley, March 2008. 